\title{
Current Trends in Urban Conservation: Medieval Historic Arab City Centers
}

\author{
Ahmed, Shehata ${ }^{1 *}$ \\ 1 Islamic Architecture Department, Umm Al-Qura University, Kingdom of Saudi Arabia, am- \\ shehata@uqu.edu.sa \\ * Correspondence: amshehata@uqu.edu.sa; Tel.: 00966500016083
}

\begin{abstract}
As Arab countries are beginning to recover from the socioeconomic impacts of the COVID19 pandemic, conservation programs are restarting. Noticeably, traditional conservation efforts have not helped improve the poor living conditions in most historic urban centers of Arab cities due to many reasons such as a lack of funds, urban management policies, and the narrow scope of conservation projects. In 2016, the UN urban agenda recognized tangible and intangible heritage as the basis for sustainable, vibrant, urban economies. These efforts reflect the new shift in conservation activities to tangible and intangible heritage and consider urban heritage a tourist product rather than antiquity. This approach grants urban vitality and sustainability for heritage areas. Thus, this study investigates the existing trends and forthcoming changes in conservation and their implication for the deteriorated historic urban city centers of the Arab world. International urban heritage conservation trends were highlighted, objectives and bases of successful urban conservation trends were reviewed, and an assessment framework was developed. Two case studies of historic centers in two Arab cities, Jeddah, and Aman, were empirically assessed using the developed framework. The findings highlight the most common urban problems of the historic centers in terms of urban management policies and trends. In addition, the impact of urban management policies on historic urban areas' sustainability, vitality, and quality was revealed. The paper ends with recommendations for conservation authorities to define a proposed framework to embed the conservation within the urban development plans for deteriorated historic urban centers. The paper's findings and recommendations can contribute to the required knowledge related to urban heritage conservation for practitioners and decision-makers.
\end{abstract}

Keywords: Arab cities; heritage conservation; urban management; sustainable built environment.

\section{Introduction:}

As the Middle East started looking to recover from the economic recession caused by the COVID-19 pandemic, lingering political conflicts, and civil unrest, heritage conservation projects began to re-emerge. No matter how old the urban heritage is, historical urban areas are considered an essential part of the local culture. It is a crucial base for cultural tourism and local society prosperity, and it is an integral part of the collective memory of the local communities. Any development project of such urban areas should carefully consider the symbology of the urban fabric and its surrounding buildings. There has been a shift among international organizations and conservation authorities to consider heritage as urban areas rather than a single monument. This shift is accompanied by increasing efforts toward engaging the local communities in preserving, managing, and controlling urban conservation plans [1].

Significant features of the urban fabric in historic Arab cities show a similar urban structure. This similarity resulted from sharing the same Islamic legislations, social characteristics, cultural heritage, environmental conditions, and construction materials [2]. The urban morphology of these cities is impacted by the social aspects of private life rather 
than geometric forms [3]. Despite the urban morphology of Arab cities having different topography, location, and climate, they all share culture, history, religious beliefs, and political circumstances [4]. These conditions are reflected in their urban characteristics. These cities were subject to colonization for a considerable period. Through this, they were all ruled with Western laws and regulations and suffered environmental deterioration [5].

Arab cities' traditional built environment is a product of the sociohistorical process, and it reflects local community values in their form of urban composition and spatial arrangement. Other physical factors, such as climate, materials, economics, and construction technology, contribute to the physical form and architectural details [6]. The historic urban fabric is a solid-built mass on which courtyards and narrow passageways are engraved [7]. The compact urban fabric, narrow shaded irregular street network, and small buildings' protected openings were environmental and social responses [8].

However, traditional conservation efforts have not helped improve the poor living conditions in most of the historic urban centers of Arab cities because of many reasons such as lack of funds, urban management policies, and narrow scope of conservation projects. From 2003 to 2019, UNESCO and ICOMOS made continuous efforts to revise the heritage definition and scope besides executing the conservation activities according to more sustainable approaches [1-5]. In parallel, The Seventeen Sustainable Development Goals (SDG), adopted anonymously by member states of the United Nations, repeatedly mention cultural aspects as the base for sustainable urban development. Moreover, the 2016 United Nations New Urban Agenda recognizes both tangible and intangible heritage as a significant factor in developing vibrant, sustainable, and inclusive urban economies and sustaining and supporting urban economies to progressively transition towards higher productivity $[4,9,10]$. Therefore, this paper investigates the existing trends in conservation and the forthcoming changes and their implication on the deteriorated historic urban city centers in Arab cities. This paper is structured in five main sections. Following the introduction, the background highlights the Arab historical centers in terms of their urban characteristics, threats, and problems. The third section presents the paper materials and methods that discuss the development of the assessment framework and assess the two case studies. The fourth section discusses the findings of assessing the two case studies. The last section is the conclusion that includes recommendations for future studies.

\section{Arab Historic City Centers}

\subsection{Characteristics of Arab Historic City Centers:}

The urban fabric was built inward, where every level of its components is contained, from its gated city walls to its quarters and local residential clusters. Even central public spaces are tightly confined. Main streets lead to local, extremely narrow cul-de-sacs, which lead by tight, dog-leg corridors to private patios. Public open spaces are enclosed by shop fronts or solid walls of the houses and gardens [6]. Narrow dead-end alleys lead the pedestrian from the public spaces to semi-public and semi-private circulation spaces. Most urban traffic serves areas for commercial and religious purposes, and city gates use main walkways. Streets are sided by many blind facades, while outside openings are covered with wooden curtains on the upper floors [11]. Historic urban areas have two types of public spaces. The first is the open public space appearing in open plazas in front of key buildings such as the mosque, market, and school. The second type is the traffic streets, represented by the narrow-structured pattern of vehicular pedestrian-oriented alleys. [4]. The narrow streets "Allayes" were a traffic control system that effectively arranged different urban functions [5]. The grand "Friday prayer mosque" courtyard acts as a gathering space [11]. In contrast, the plaza in front of the grand mosque and other public buildings serves as circulation distribution nodes to and from the lower category neighboring paths. A wider space often appeared along the central path spine of the fabric. The size of this space depended on its location within the urban fabric and its accommodated pedestrian traffic [3]. Physical borders are loosened in those spaces and extend the bazaar 
to accommodate the informal commercial and social activity. Urban heritage researchers indicated a typical unwritten relationship between the width of streets and their bounding buildings' heights [5]. The main feature of the Islamic city's land use is the clear separation of commercial from residential areas. All markets are within the central zone. The city's central urban area is distinctive by its relatively large, straight streets leading directly to the old main gates [8]. In historic Arab cities, there has been a significant contrast between commercial crowded streets and the quiet calm of the private courtyards [6]. The network structure of the open spaces is based on controlling access and mobility, and doors were used to manage social contact, even in streets where no entries were allowed to open in front of another [12,13]. Moreover, the courtyard concept is a crucial element, utilizing open space surrounded by private usage. The effective use of courtyards allows to narrow lanes and interrupts perspectival alignments [11].

2.2 Endangered Arab Historic City Centers

Urban settlements evolve and change to fulfill their inhabitants' requirements. Over the past century, historic city centers have struggled between their symbolic significance as a heritage with a distinctive sense of place and many political and economic development programs [11]. Correia argued that the city center is retail mainly with many independent retailers such as cafes, antique stores, and fashion boutique shops with aboveaverage geographical catchment areas $[14,15]$. The historic urban centers are not isolated individual areas. Areas surrounding historic centers constitute an interface between the historic center and the rest of the city's expansions and complements [16]. These districts adopt the same urban identity.

In the course of time, climate and religion have lost their influence over historical cities and their urban character. Globalization and modern technologies took over and enforced certain practices, spaces, and forms on the Islamic urban fabric [17]. The requirements of everyday life coupled with economic growth had a destructive impact on the urban heritage of the historic centers of Middle Eastern cities [2]. The physical characteristics of open spaces have changed, but they still follow the same traditional sociocultural system. Western urbanism theories differentiate a city from a town by its functions and size; the Arab terminology uses "Almadina" to indicate a city and "Albalad" to indicate a town. "West-Albalad" refers to the vernacular urban center and is used nowadays as the historic city center [18].

\subsection{Urban Problems of Historic Centers}

Historic centers within Arab cities have something in common: they are all about to lose their historical identity and urban character. Many researchers have identified problems related to the urban changes of historical centers $[3,19,20]$. The car has had a significant impact on city planning through the last century [21]. In the case of Arab cities, what was once a pedestrian-friendly traffic network with narrow shaded alleys has had to accommodate a vehicular-based traffic system with paved roads. As a result, historic city centers ended up with congested traffic networks, districts separated with wide streets, and dissolved social culture, including the following factors [1,22]:

Physical: Large buildings started to take over the city scene [3]. More traffic has led to a more congested traffic network. Creating wider spaces increased the thermal loads on buildings, and extra thermal loads pushed for more HVAC dependency. More HVAC left the outdoor spaces subject to the harsh weather.

Socioeconomic: As part of the vertical immigration within the cities, original residents deserted their historic low service areas and were replaced with residents from different classes with different cultural values and habits. The informal economy flourished and impacted the local business owners badly $[19,23]$.

Environmental: The internally-oriented built environment used passive cooling strategies, today transformed into outward-looking with unprotected open spaces and depending heavily on mechanical air-conditioning systems $[8,24]$. Unserviced areas with deteriorated built environments began to be deserted by their residents.

\section{Materials and Methods:}




\subsection{Theoretical Background and Contextual Approach:}

Bruno Favel [25] cited three different changes for the heritage definition: the first defined it as a monument embodying the nation's values. Later, the definition expanded to include private monuments, monuments in their environmental context, neighborhoods, every day, and immaterial heritage. Finally, the definition expanded to include the historic urban landscape. This definition requires a profound understanding of the living and inhabited landscape. As the concept of heritage evolved, the intangible heritage and culture have been recognized as heritage $[25,26]$. Cultural heritage was defined in the first article of UNESCO's Operational Guidelines of the World Heritage Convention as groups of separate or connected buildings. The unique universal value of these monuments comes from their architecture, homogeneity, or place in the landscape, and this value is evaluated in the light of history, art, or science. Moreover, article 47, in the same document, defined the cultural landscape as manmade, either integrated within natural sites or not. This heritage includes archaeological sites characterized as ethnological, archaeological, historical, or aesthetic [27]. Moreover, the third annex of the guidelines listed five categories as heritage: cultural landscape, historic towns and downtowns, heritage canals, and heritage routes [27-29]. Since then, the heritage definition has expanded to include all aspects of culture such as language, food, and arts [30]. Preservation authorities worldwide began to consider protecting the intangible components of the urban heritage in their preservation and restoration projects [25,31].

Urban heritage reflects the identity, memories, and authenticity of the local community. It has been the source of civic pride and should be the driving force behind any restoration efforts [18]. Prosperous urban areas attract visitors to participate in cultural activities within their open public spaces. [32]. There is a growing shift in heritage research trends toward considering it a dynamic process $[19,22,23,33,34]$. Urban heritage should be first defined for its cultural value to a group of people; then, effort should be made to conserve it and pass it on to future generations. This process is what can be described as the heritage circle [25]. Hall proposed this process as a "cultural circuit" that explains how the intangible heritage is constructed through cultural production, representation, and consumption. Smith emphasizes urban heritage as a cultural process of remembering the work, creating ways to understand it, and engage it with the present. He also argues that the tangible elements are the cultural tools for facilitating this process [18,35]. Moreover, he claimed that the potential social value of heritage was first recognized in 2005 in the Australia ICOMOS Article 1.2 when the previously used terms "monument" and "site" were replaced by the broad term of "place" as a heritage subject for conservation $[36,37]$.

The Burra Charter identified the need to involve people in different phases, particularly those with solid cultural significance. In Article 3.1, the Burra Charter stated that locals linked to urban heritage should have the opportunity to contribute to understanding the place's cultural importance and participate in its conservation and management whenever this is appropriate [36,37]. At the same time, Article 3.2 of the Burra Charter protected the symbology and physical characteristics of the urban heritage from change through development activities [36]. Article 30 of the same charter took extra measures by deciding that all conservation phases should be supervised and conducted with the appropriate skills and knowledge $[31,36]$.

In the URBAN II urban regeneration funding program, deteriorated urban areas were defined as areas with deteriorated economy and high unemployment, crime, school dropout rates, and a deteriorated physical and social environment [38]. Tallon describes the reasons for historic city centers' deterioration as the emerging hyper-shopping centers, the demographic change caused by socioeconomic movement, traffic congestion, and deteriorated physical conditions $[39,40]$. Researchers and urban writers have highlighted the importance of managing urban growth for city management administrations and the residents [41]. Urban management describes policies to control and regulate urban growth and development $[21,22,30,42]$. 
Urban management is often defined as a set of controlling actions. These actions specify the nature, location, scale, and scheduling of intervention. Several alternatives of government intervention degrees for reversing the urban deterioration include regeneration, revitalization, and gentrification $[39,40]$. The following defines some of these policies: "Regeneration" is a comprehensive, integrated process to achieve long-lasting physical, socioeconomic, and environmental resolutions for the designated urban area problems. These processes should be part of a longer-term strategic development urban plan. Urban Regeneration is more likely to be linked to public participation and community involvement. $[1,39]$. The parallel terms used in the USA are new urbanism, sustainable communities, and smart growth [39]. "Revitalization" has almost the exact definition of regeneration, but revitalization is more oriented to community programs, including education, housing, and health services, as well as physical policies [39]. The term "gentrification" is defined as the process of creating an urban area that attracts skilled workers, innovators, and investors. At the same time, it provides chances for better living conditions for all of its residents and investors [39]. Heritage conservation within Arab cities has been focused on physical and materialized forms.

Up to now, the value of intangible heritage has never been a subject of concern or appreciation [18]. Smith argued that the increasing international interest in heritage and the re-evaluation of modernity came as a response to the rising concern of globalization in the late twentieth century. Smith also highlighted the conflict among native groups in defining identity and narrative or symbolic meaning [35]. Furthermore, Smith argues that the conflicts extend to the economic realm, where developed counties enforce their concepts of heritage and tourism via the international financial and heritage organizations such as UNESCO, ICOMOS, and the WTO [35]. The first use of the term conservation was in the Venice Charter dated 1964, which regulated the definition and practice of Conserving and Restoring Monuments and Sites [43]. This charter reflected international awareness of heritage conservation, defined the guidelines to conservation practice, and paved the way for all Western practices in this field [18]. Later, in 1972, the World Heritage Convention regarding the protection of the world's cultural and natural heritage was adopted by the UNESCO General Conference to mitigate the deterioration threats to the international heritage sites coupled with the fast social and cultural changes worldwide $[25,29,34,44]$.

As cited by K. Ashour, Roberts defined successful regeneration as conserving the physical urban fabric, supporting social structures, creating an economic base, and improving environmental conditions, following sustainability principles [39,45]. It must have clear, measurable objectives and tools to measure it, utilize resources efficiently, and involve all stakeholders. Moreover, Montgomery suggested that prosperous cultural urban areas have a mixture of activity, meaning, and authenticity. They have to be flexible, innovative, changing, and adaptive [46]. Such sites need to have diversity in land use, richness in leisure and dining facilities, and workspaces for media and art education studios. Its fabric needs to be conserved with fine-grain urban morphology, with quality of vibrant public spaces, busy streets, visitor attractors, and pleasing streetscapes. They should have a sense of history, character, identity, and environmental signifiers. Such areas should remain maintained to play their cultural roles [46].

\subsection{Method: Theoretical Assessment Framework for Historic Centers}

A few researchers discuss the assessment of conservation activities. Efficiency and effectiveness measures are the basis of any acceptable assessment framework, and an empirical assessment provides information on issues of measurement of conservation outputs. Moreover, it highlights the usefulness of adopting specific indicators assessing the conservation decision-making process [26]. This assessment process is more straightforward in cases of physical heritage conservation, while in the case of intangible heritage, it is much more complicated. Ilde Rizzo, as cited by Pietro, highlighted the following arguable assessment issues: scope, priorities, intervention strategies, preservation strategies, 
and long-term outcomes $[47,48]$. The newly adopted definition of heritage comprises the physical urban environment and intangible cultural values. In such cases, conservation activities must be embedded within the urban development plans, and residents' participation in different phases of conservation is required [22]. Samrqandi, in her evaluation workflow, defined six attributes for the evaluation of heritage places: access and linkage, comfort and image, uses and activities, sociability, context and conservation, and site interpretation [12]. Abou-Soliman suggested five physical features for vibrant urban heritage: accessibility, having a suitable scale and form for located activities, accommodating appropriate usage, encouraging visitors' activities, and infrastructure and services to support designated activities. He also suggested seven intangible features for thriving urban heritage: vibrant, readable, defined, meaningful, safe, symbolic, and encouraging [49].

Indicators are required to evaluate the success of any culture or heritage conservation-related programs. They must be conceptually based and simplified to be practical. Traditionally, experts and professionals make indicators' selection [26]. Nevertheless, stakeholders select the indicators for urban heritage, and the section requires community empowerment and engagement in sustainable environmental management and defining the heritage values [19]. Researchers in conservation, economics, sociology, and environmental fields have proposed different indicators to assess their area of study activities, with the leading indicators for each of these intersected fields of heritage conservation assessment [50]. Areas of conservation sustainability assessment overlap between these fields, as shown in Figure 1.

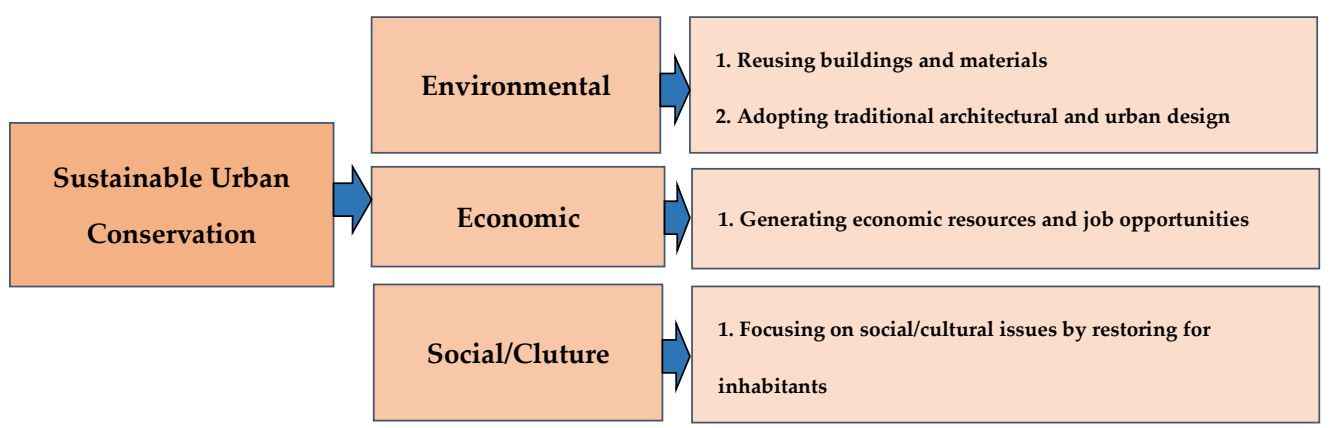

Where:

Figure 1: Sustainable historic conservation strategies.

- Environmental indicators cover sustainable conservation activities in terms of consumed materials, energy, and other resources. They also cover the environmental impacts of cultural tourism and social sustainability in sustaining existing social structures, territories, identities, and social capital [26].

- Economic impacts which involve direct benefit, cost-effectiveness, choice modeling, nonuse values, community wellbeing, and wealth distribution by tourism [26,38];

- Social, covers areas of income, education, social and behavioral habits, and all define a community's distinctive characteristics [47,51];

- Cultural indicators which cover form and design, construction systems and local materials, use and function, settings, and all intangible heritage forms, such as language, traditions, location, and spirit and feeling [15,33];

Table 1 summarizes the main areas and indicators for these intersected assessment areas based on the literature for this topic. Four main areas involve the conservation activities impact areas: social, economic, environmental, and cultural. The presented indicators in the table are examples and should be collected before and after implementation.

Table 1. Areas and indicators of urban conservation impact assessment.

\begin{tabular}{ll}
\hline \multicolumn{1}{c}{ Assessment Areas } & \multicolumn{1}{c}{ Assessment Indicators } \\
\hline Environment & Consumed Materials, Resources Management System, Waste \\
& Management System. \\
\hline
\end{tabular}




\begin{tabular}{ll}
\hline Economic & Direct Benefit, Cost-Effectiveness, Nonuse Values, and \\
& Wealth Distribution. \\
\hline Social & Income, Education, Social Habits, Behavioral Habits, Sense of \\
& Identity, Sense of Belonging. \\
\hline Cultural & Form and Design, Use and Function, Materials, Location, \\
& Setting, Traditions, Spirit and Feelings \\
\hline
\end{tabular}

\subsection{Common Urban Problems of Historical Centers:}

The most common problem in historic city centers in the Arab world is that they have been dealt with through local urban planning departments as deteriorated low-class urban areas, and they have never been seen as cultural heritage [50,52]. Lack of funds and unsuitable urban management plans were the main reasons these fragile centers lost their character and identity [4]. Historic urban areas were either demolished through urban replacement development programs, for example, in Makkah, where the whole historic center of the city was demolished and replaced with tall Western-style buildings $[4,49]$. Meanwhile, many heritage urban areas of Cairo suffer from the government's plans to create a new wide traffic axis dividing these areas into separated islands [8].

\subsection{Case Studies}

Two historic sample centers were selected to investigate the impact of the management policies on the urban condition of these fragile built environments. Jeddah's historic center was chosen to represent cities within the wealthy Arab countries, and historic Jeddah received much attention from both the national and international heritage authorities. Despite the availability of generous governmental funds, the historic center suffers as much social and environmental deterioration as the rest of the region's historical centers. The second city was the "Amman Historic center," which lacked funds and depended mainly on international aid for conservation activities. As mentioned by Smith, international aid usually comes with predefined priorities and the scope of conservation [35]. Conservation efforts and urban management plans aimed for socioeconomic uplifting to mitigate the requirements of the booming number of refugees within the city.

\subsubsection{Amman City}

Despite Amman City's historical background, its first existence as the city we know today started in the early twenties of the last century, the Ottoman era, as an intermediate Junction on the Hijaz train line. Amman's population at that time was about 5000 inhabitants, in an urban area of $0.321 \mathrm{~km}^{2}$. Amman has been the fastest growing city globally in the past few decades due to several immigration waves from neighboring countries [21,41]. In 2020, Amman had an urban area of around $0.321 \mathrm{~km}^{2}$ with less than five million inhabitants in the latest available statistics. Figure 1 illustrates a tempo map for the urban city growth [53-55].

\subsubsection{Amman Historical Center "Albalad":}

As shown in Figure 2, the historic Amman or "Albalad" used to be the main market, administrative center, and transportation hub, surrounded by residential areas on the neighboring hills. The hills' topography and valley shape influenced the pattern of the physical development of the 182 hectares of the historic city. The urban pattern adopted the natural physical form. The city expanded following the contours up to the surrounding hilltops. The neighborhoods were connected via stepped alleys as pedestrian links to the city center [39,41]. In addition to its traditional urban, wholesale market, and leisure facilities, the "Albalad" area is near archeological sites with monuments from different eras, such as the mountain castle, the citadel, Hercules temple, the Roman theater, the Umayyad palace, and the Alhosainy Grand Mosque [18,41]. 


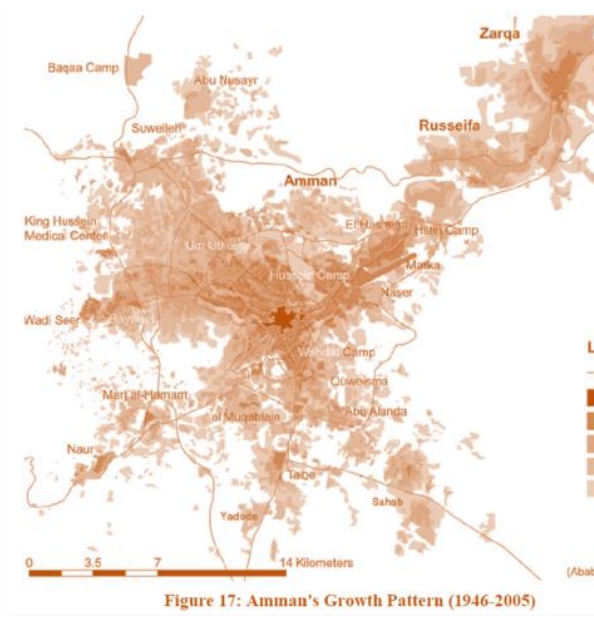

Figure 2: Amman City's urban growth (1946-2005) [41].

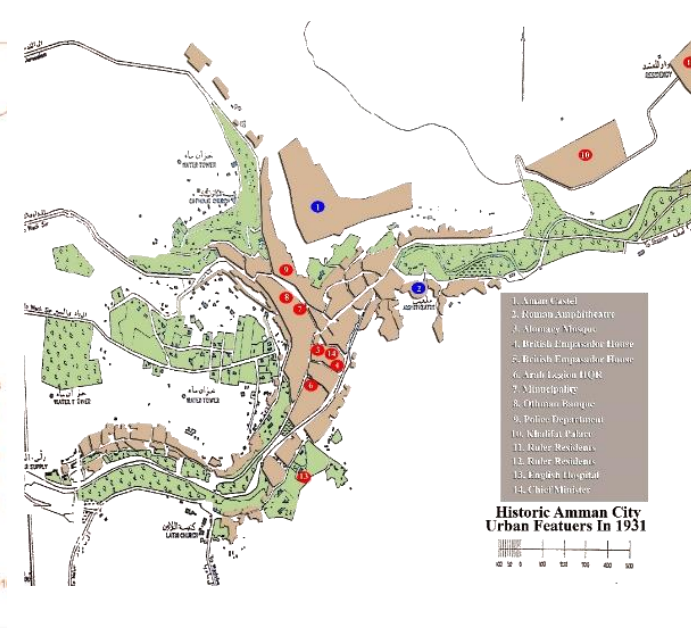

Figure 3: Historic urban features of Amman City. Dated 1931. Source: Adapted from Department of Lands and Survey, Transjordan cited in [41], reproduced by the author.

\subsubsection{Conservation Activities}

Amman City was subject to several development plans. In 1955, a development plan was approved by Greater Amman Municipality (GAM) to mitigate the growing demand for housing, services, and the lack of job opportunities [41]. Later, in 1968, another master plan was suggested to manage the fast-growing informal settlements, lack of services, road congestion, centralization of business and commercial activities, and high unemployment rates. In 1978, a Japanese firm (IECA) proposed relieving the growing traffic congestion and increasing municipal revenues. The final master plan for the city was proposed and approved by the GAM for a period from 2008 to 2025. This master plan was a comprehensive, multilevel sustainable plan. Moreover, this plan came as a participatory effort of all stakeholders. The masterplan framework defines urban policies, strategies, land use, legislation, and public participation [21]. The main objective for the historic center reservation was to improve its local economy and social cohesion, recover its centrality within the city, and revive its authenticity and social cohesion. The tools to achieve these objectives were creating spaces for everyone and preserving the cultural heritage with symbolic values. Creating a high-quality environmental and social urban fabric would create a tourist commodity. Increasing tourism activities would create a prosperous community [41]. Participatory community activities helped attract private investment and created an envi- 
ronment for businesses and community involvement projects [41]. The action plan's proposed projects shown in Figure 3 were adopted to achieve the objectives for the Albalad area.

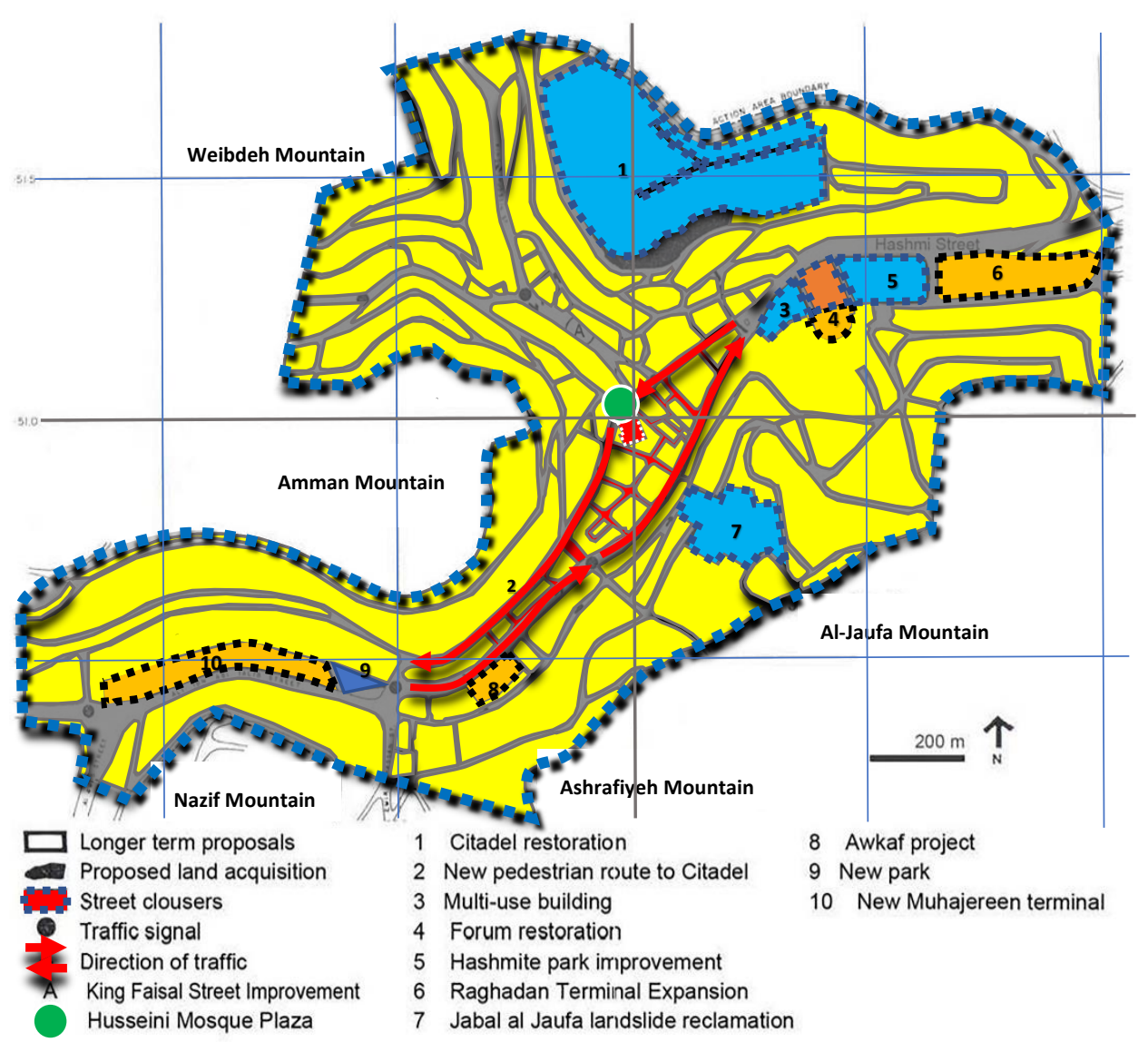

Figure 4: Spatial distribution of "Albalad" Conservation Action Plan.

\subsubsection{Current Urban Management Plans}

The current master plan includes the following multidirectional urban management programs:

- Re-establish the Albalad as a commercial destination by conserving the existing traditional market's character. Regulate the informal street retailers to achieve a vibrant street mall with good urban design qualities and enhance the specialized and thematic commercial areas.

- Define cultural heritage buildings and districts. Conserve and adapt reuse of heritage buildings. Implement guidelines for heritage protection, encourage artistic and cultural activities.

- $\quad$ Establish connections between the public realm and its surrounding areas through pedestrian and public transport routes and public and commercial spaces. Improve the image quality of public space and create gateways and thematic landmarks.

- $\quad$ Preserve the existing urban physical character in terms of form and visual relationship with surrounding hilltops.

- Support tourism by enhancing the heritage district spirit, defining the tourist pedestrian routes, and providing tourist services and cultural activities.

- Create an entertaining district by establishing a mixed-use character of specialty retail, cafes, and restaurants. At the same time, make arrangements to hold entertainment venues, festivals, and cultural events.

2.4.1.4. Impact of Implemented Development Actions 
Amman's downtown development plan is still in progress. Urban management in terms of enforcing regulations and legalizations successfully revitalized the area as a traditional commercial center. It has created cultural and public spaces facilitating cultural and artistic events. The adopted public uses for the first floor of buildings on selected historical paths for cafes and restaurants created unique and vibrant public spaces. Traffic arrangements and transportation plans helped in easing congestion within the area. Table 2 presents a subjective assessment of the historical center's conservation activities.

Table 2: Subjective assessment of urban management plans of the "Albalad" area (Amman City).

\begin{tabular}{|c|c|}
\hline Area & Assessment \\
\hline Environmental & 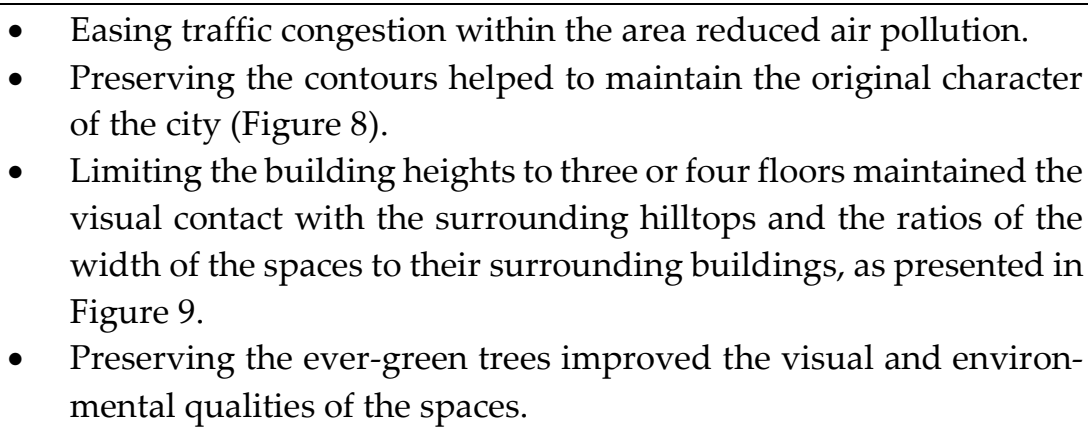 \\
\hline Economic & $\begin{array}{l}\text { - As the COVID-19 pandemic impacts started to decrease, the area } \\
\text { flourished with visitors from other cities and the region. Photos in } \\
\text { Figure } 6 \text { show the vibrant spaces of the city. } \\
\text { It is worth mentioning that permitting the first floors of traditional } \\
\text { buildings to accommodate cafes and restaurants, as shown in Fig- } \\
\text { ure } 7 \text {, doubled the commercial spaces of the limited historic urban } \\
\text { zone. }\end{array}$ \\
\hline Social & $\begin{array}{l}\text { - Many residents do not originate in the city and have no sense of } \\
\text { belonging; they still enjoy the center and benefit economically, as } \\
\text { shown in Figure } 4 \text {. } \\
\text { - Food, touristic gift shops, cultural events, and cleanly maintained } \\
\text { walkways give the public spaces a vibrant image, as illustrated in } \\
\text { Figure } 5 \text {. }\end{array}$ \\
\hline Cultural & $\begin{array}{l}\text { - Archeological sites lack services, and their surroundings are not } \\
\text { well-maintained, as shown in Figure 10, which exhibits the physi- } \\
\text { cal conditions of the nearby Castel mountain archeological site. }\end{array}$ \\
\hline
\end{tabular}

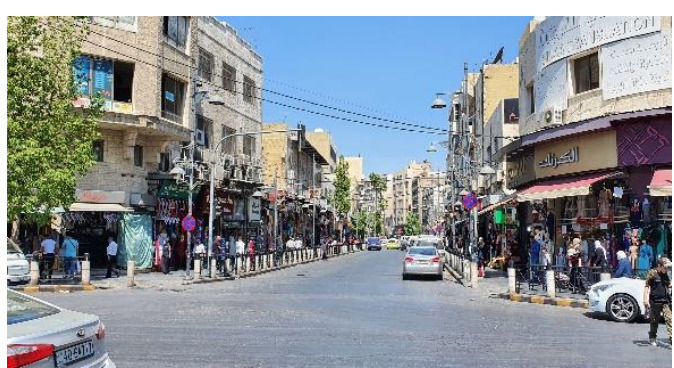

Figure 5: Commercial activities created vibrant streets. Source: The Author.

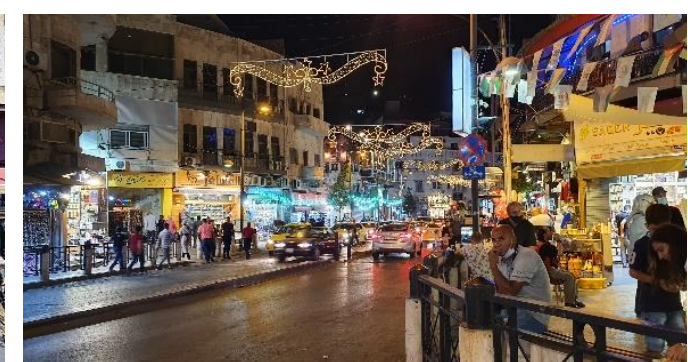

Figure 6: Food, touristic gift shops, cultural events. 


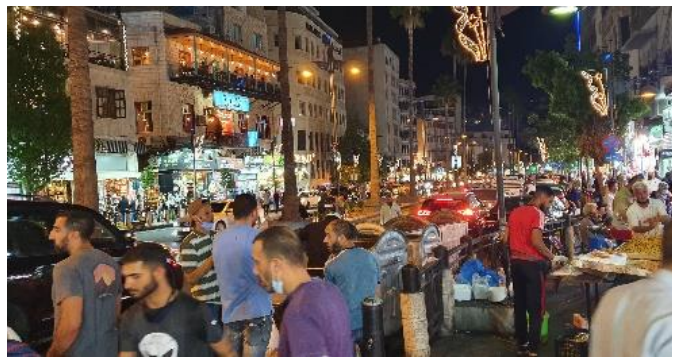

Figure 7: Vibrant, safe activity in the Albalad area. Source: The Author.

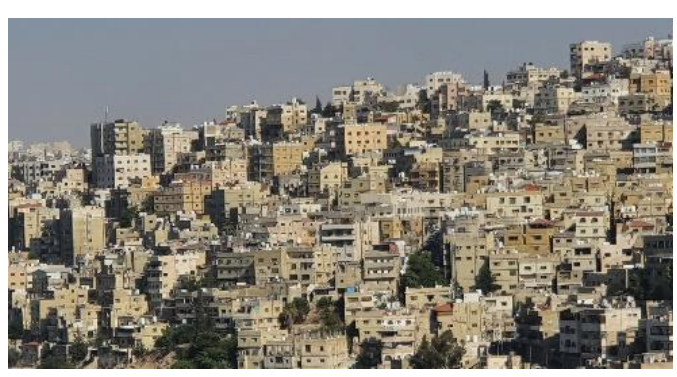

Figure 9: Preserving the contours maintained the city's original character. Source: The Author.

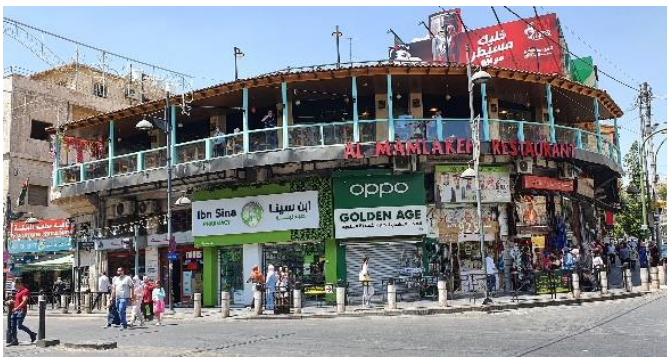

Figure 8: First-floor entertaining activities doubled the commercial use of the area. Source: The Author.

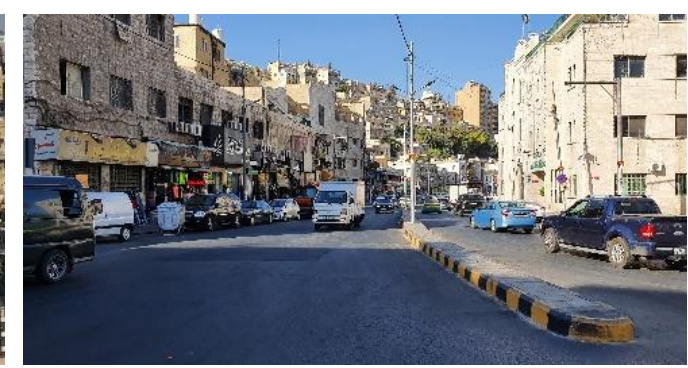

Figure 10: Limiting building heights to three floors maintained the visual character. Source: The Author.

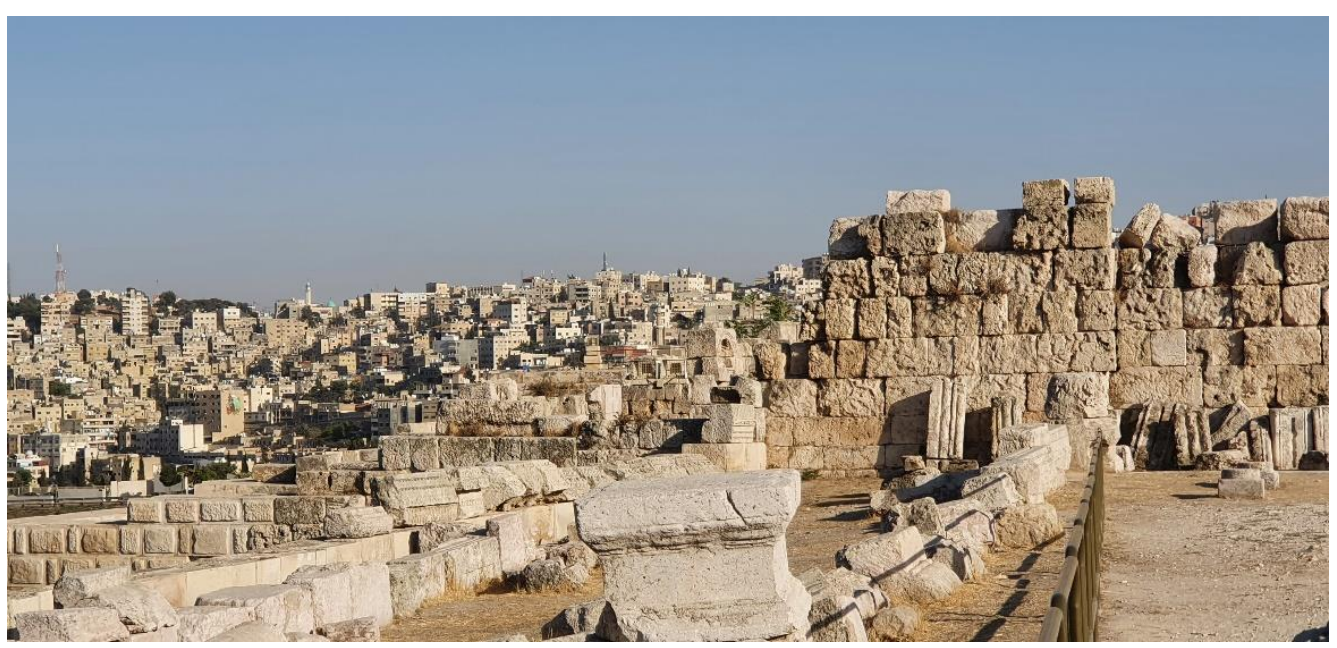

Figure 11: The physical conditions of the nearby Castel mountain archeological site.

\subsubsection{Jeddah City}

It is the economic capital and the main port of the Kingdom of Saudi Arabia. With more or less five million inhabitants, Jeddah is the second-largest Saudi city after Riyadh. It belongs to the Red Sea civilization. Jeddah is one of the oldest cities in the region, and it was inhabited about one thousand years before the Crist and has been a trading hub for the region since then [56]. Most of the urban fabric, city walls, the six gates, and residential and public buildings belong to the Ottoman era of the 15th century. Jeddah's modernization started with the Saudi Kingdom. In this area, the city has witnessed several changes.

Historic city walls and gates were demolished in 1948: the city expanded to the north, a new port was established to the south, and an airport was constructed. Later in the 1970s, shopping malls and office buildings were built in the demolished western part of the historic city. A new road network and parking facilities were built to meet the newly growing 
demand of its inhabitants [56-58]. Figure 11 illustrates the city's growth over the six decades. Due to these modernization activities, the historic district of Jeddah that was once an entire walled city, had become a tiny area within the city itself. The historical Jeddah lost whole sections of its original urban fabric. The new modern buildings were concentrated in the city's neighborhood next to the seashore [50,56,59]. During the 1980s and 1990s, the area was no longer able to provide the requirements of contemporary life for its original residents, and they abandoned the area and moved gradually to the wealthy, newly developed areas to the north. Over time, the area started to decline in its economics and social characteristics and converted into an entirely rented area for poor foreign immigrants [58].

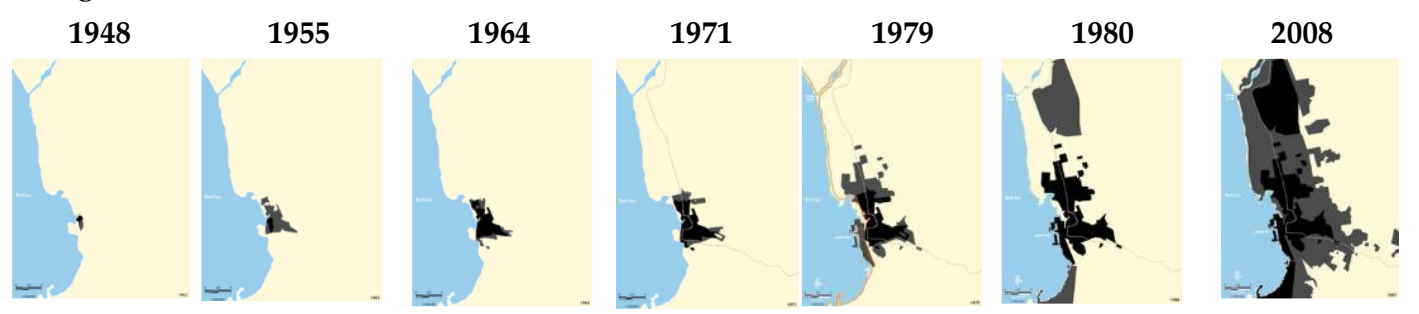

Figure 12: Historic Jeddah's urban growth through the last five decades [33].

\subsubsection{Jeddah Historical Center}

Historic Jeddah, known as Albalad, extends over seventeen hectares, and it symbolizes the heritage and culture of the city. The cityscape of historic Jeddah resulted from an exchange of local culture, environmental conditions, technical construction systems, and materials [60]. Its architectural style is characterized by three- to four-storey coral stone residences, decorated with openings covered with wooden "Roshan" [24]. Figure 12 shows the location and spatial organization of these houses. The area's outstanding universal value is based on its unique architectural style and urban character [60,61].

Furthermore, Historic Jeddah "Albalad" is considered the last preserved original urban context within the region. Figure 13 illustrates historic subdistricts and the unique premodern urban landscape, with narrow irregular alleys and small public spaces. The pictures in Figure 14 illustrate the urban character, diverse, multicultural population, and active, well-maintained Alalawy Street-vibrant public spaces that still play a significant cultural symbology role in the local community.

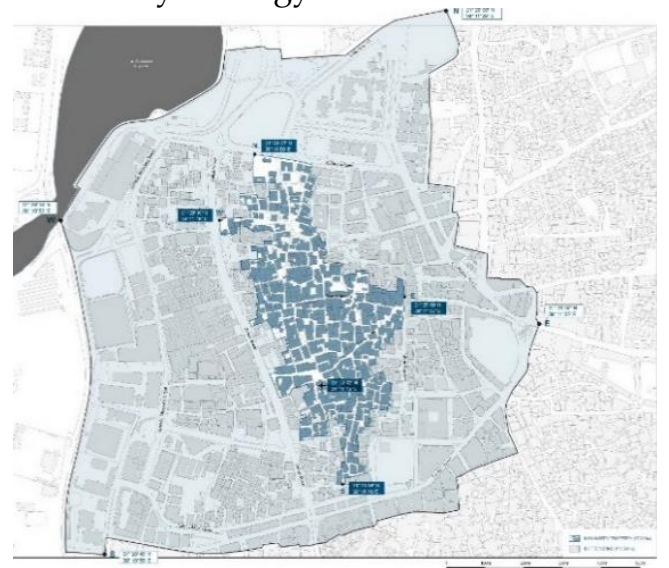

Figure 13: The listed group of buildings within the Albalad area [61].

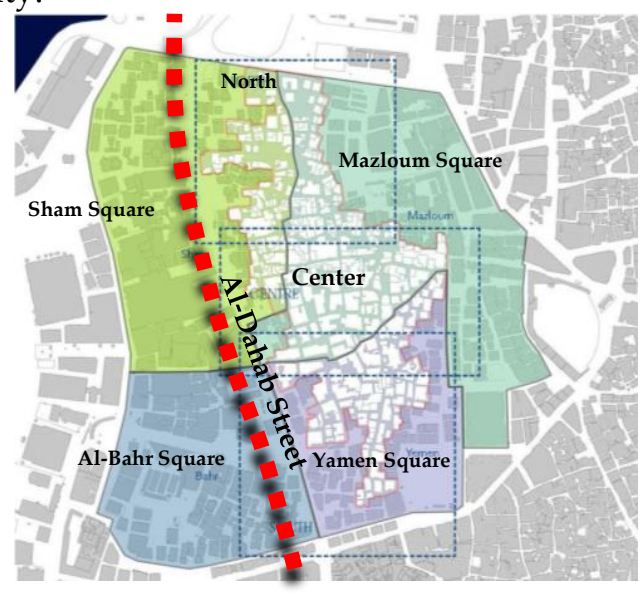

Figure 14: Districts of Albalad area. 


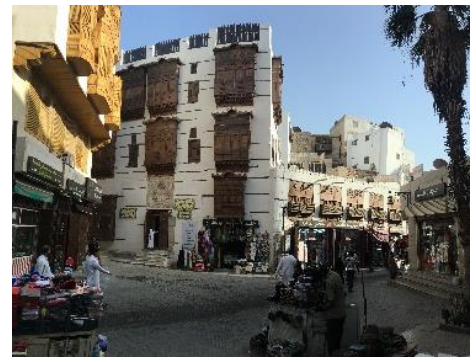

(a) Qabil Street.

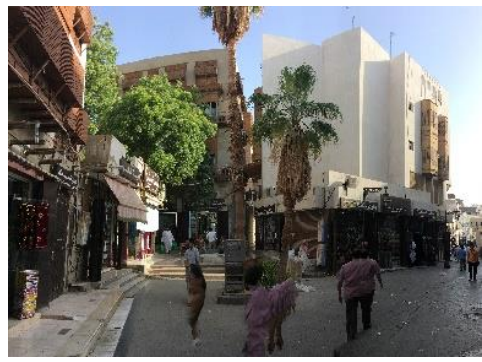

(b) Alalawy Street.

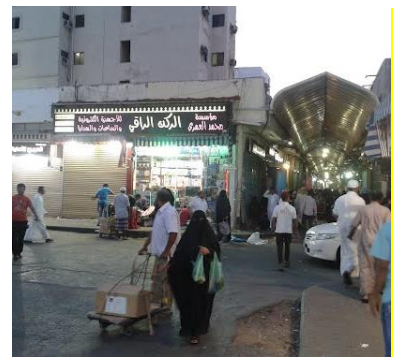

(c) Algamea Street.

Figure 15: (a) Area's urban character; (b) Maintained urban spaces in Alalawy Street, (c) Commercial activities at Algamea market.

\subsubsection{Conservation Activities}

Efforts to maintain, conserve, and protect the Albalad area has continued through the last decades. In the 1970s, the area was subject to urban upgraded plans where new malls and office buildings replaced the coastal sector of the site. The city walls and gates were removed to ease the city's accessibility, and a new main road, "Al-Dahab Street," was created parallel to the sea was constructed to meet the growing traffic demand requirements. Some buildings were subject to significant restoration, and three of the city gates and some of the remaining city walls were restored [50,56,62]. From 2003 to $2011 \mathrm{CE}$, the King Abdul Aziz Project for the Preservation of the Historic District of Jeddah was launched at the organizational and administrative levels. Policies related to heritage buildings were developed. The Department of Architectural Development was established in the region, which formed the nucleus of the current Jeddah Historic District Municipality. A reference guide was adopted to restore heritage buildings and storefronts. The heritage buildings in the Jeddah Historic District Municipality complex were also restored $[60,62]$.

Moreover, through collaborative efforts between the Municipality and the wealthy merchants within the city, some residential buildings, mosques, rabats, and markets were restored. Parallel to these efforts, a major urban landscape project was carried out to update spaces within the area. This project includes unifying the colors and size of the shop signs, adding designed lighting units and infrastructure, implementing the first phase of the firefighting network, maintaining the alleys' paving work, and reducing the vehicle traffic within the area [52,63]. In 2012, a new urban legislative framework was enforced, providing legal tools to control the speculative movements that once triggered the loss of some historic buildings. The map in Figure 15 shows the protected urban zone and its neighboring four districts. Each one of these districts follows different building regulations. In 2014, the site was granted UNESCO World Heritage status; several traditional buildings have been restored and opened to the public [56]. In 2019, the Saudi crown prince issued a royal decree to restore 50 historic buildings within the historical site [62].

\subsubsection{Current Urban Management Plans}

The UNESCO did not list the whole area but selected a group of buildings. As a result, there are two different lists of heritage buildings, one listed by the Municipality and some listed by UNESCO. Based on this, the protection system divides the urban area into four categories [25,64]. Figure 16 illustrates these categories and what Jeddah Municipality defined a larger urban ring as a transitional buffer area around the perimeter listed area by UNESCO. This area comprises the 1950s and 1960s' expansion of Jeddah beyond the city walls. Building regulations for this outer "ring" aimed at creating a smooth transition between the historic area and the city's modern designed expansion. This urban ring development program focuses on creating large-scale structured urban blocks $[25,56]$. The 
plan aims to increase accessibility to the inner neighborhoods while preserving the original organic urban fabric, land use, building heights, and densities. Moreover, it targeted updating infrastructure and providing all the necessary social and technical infrastructure to the residents [60].

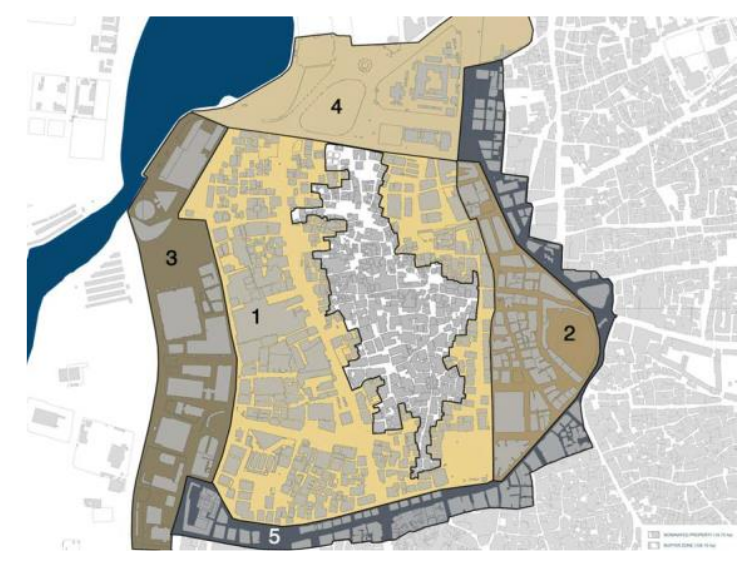

Figure 16: The buffer zone around the listed heritage [36].

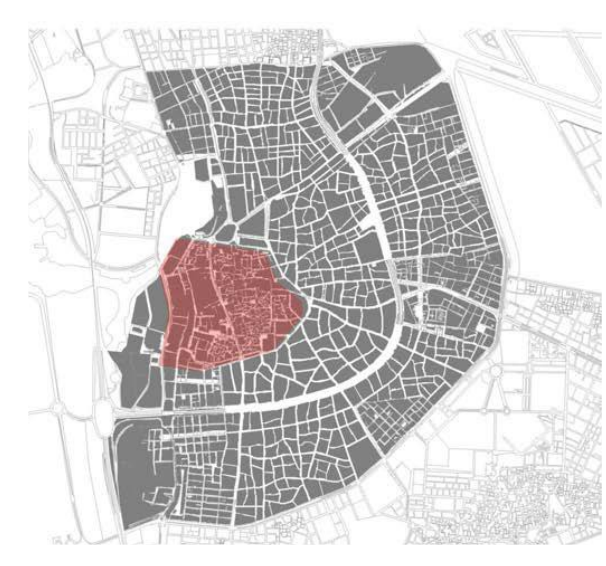

Figure 17: The buffer zone around the listed heritage [36].

\subsubsection{Impact of Implemented Development Actions}

The enforced land-use legalization for ground floors as commercial and first floor as offices helped create vital active spaces during shop working hours [29-33]. The typical floor spaces did not attract companies to utilize the traditional residential spaces with tiny rooms and poor utilities. Shop renters used the spaces informally as a store and housing for their workers. This use endangered the valuable, fragile buildings and created risky alleys to walk through after the shops' opening hours [50,65]. It is worth mentioning that several fires in the last five years resulted in the demolition of several of the list buildings $[62,64]$. At the same time, buildings that were subject to maintenance were locked without any usage, resulting in the fast decay of these buildings. The building regulations for areas one and two, shown on the map in Figure 15, permit owners to have up to twelve floors to combine plots to achieve a larger plot area. This building permit system badly impacted the homogenous skyline and width-to-height ratios of the narrow alleys. Otherwise, the urban spaces are well maintained and vibrant, especially during the Ramadan night season, when daily activities extend for a whole month in the northern part of the historic area. The area is still considered the city's wholesale market for honey, perfume, cloth, toys, etc. [4,56,64]. Table 3 summarizes the subjective assessment of the implemented conservation strategies and the ongoing activities in the Albalad area of Jeddah city.

Table 3: Subjective assessment of the development of the "Albalad" historic area (Jeddah city).

\begin{tabular}{ll}
\hline $\begin{array}{c}\text { Area of } \\
\text { Assessment }\end{array}$ & \multicolumn{1}{c}{ Assessment } \\
\hline Environmental & - $\begin{array}{l}\text { Creating paid parking along the surrounding streets pushed } \\
\text { shop owners and shoppers to use the narrow alleys to make a } \\
\text { full-time traffic-congested zone. This traffic congestion within } \\
\text { the area increased air temperature, heat, and air pollution. }\end{array}$ \\
- & $\begin{array}{l}\text { Allowing owners of unlisted buildings within the same area to } \\
\text { build up to thirteen floors changes the architectural and urban } \\
\text { character of the area, as shown in Figure 19. }\end{array}$ \\
- $\begin{array}{l}\text { Due to the hot, humid weather, contemporary urban areas } \\
\text { within the city are not walkable. In contrast, this area is walkable } \\
\text { because of the shaded, naturally ventilated alleys. }\end{array}$ \\
\hline
\end{tabular}




\begin{tabular}{|c|c|}
\hline Economic & $\begin{array}{l}\text { - The area receives many shoppers, the wholesale market of many } \\
\text { products such as honey, makeup, clothes, spices, stationeries, } \\
\text { and gifts. } \\
\text { - It is worth mentioning that allowing the first floors of traditional } \\
\text { buildings to accommodate only office use did not help create vi- } \\
\text { brant public spaces. } \\
\text { - Historic buildings owners are not motivated to maintain, con- } \\
\text { serve, or preserve their buildings despite the governmental in- } \\
\text { centives and interest-free loans. Figure } 18 \text { illustrates the lack of } \\
\text { owners' interest in conserving their properties that caused the } \\
\text { loss of many historic buildings. }\end{array}$ \\
\hline Social & $\begin{array}{l}\text { - Current area residents do not originate in the city and have no } \\
\text { sense of belonging; they still benefit as shop vendors. Figure } 17 \\
\text { shows the spread of commercial activities along all the alleys. }\end{array}$ \\
\hline Cultural & $\begin{array}{l}\text { - Cleanly tiled alleys, stylish lighting units, and unified shop signs } \\
\text { give the visitors a good impression, as illustrated in Figure } 20 \text {. } \\
\text { The Antiquities Authority started to arrange annual cultural } \\
\text { events through Ramadan nights. These events attracted city res- } \\
\text { idents, reminded them of their intangible culture, and raised the } \\
\text { spirit of pride and belonging once again, as Figure } 21 \text { shows. } \\
\text { - The buildings have a unique architectural style, and the in-be- } \\
\text { tween urban spaces and their composition is one of the oldest } \\
\text { and most unique in the region. Figure } 22 \text { shows a sample of the } \\
\text { authority's efforts to maintain it. }\end{array}$ \\
\hline
\end{tabular}

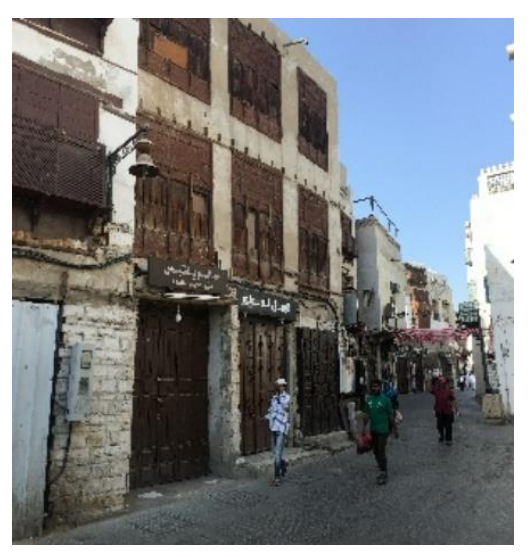

Figure 18: Spread of commercial activities along all the irregular alleys.

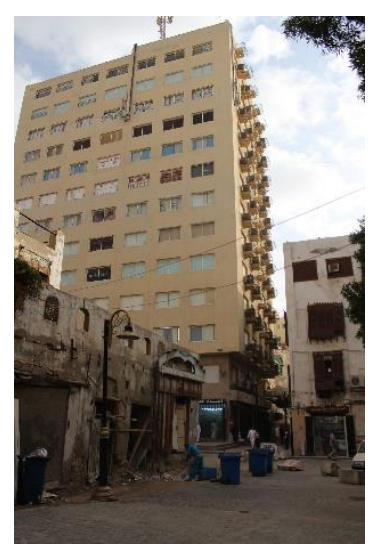

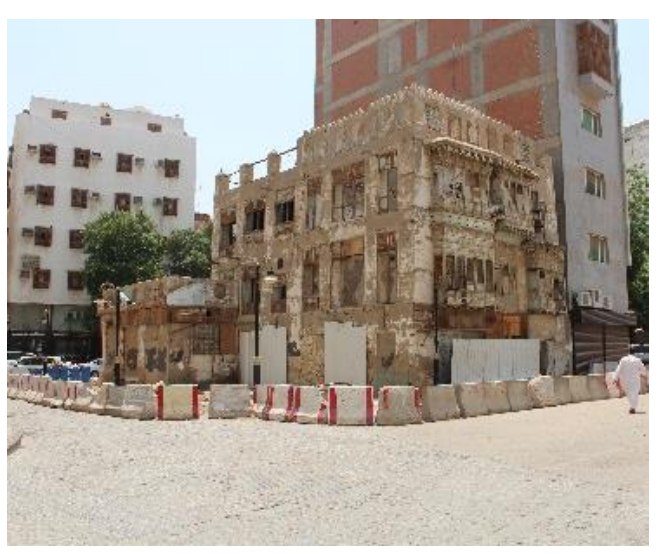

Figure 19: Buildings' owners are not motivated to conserve their properties.

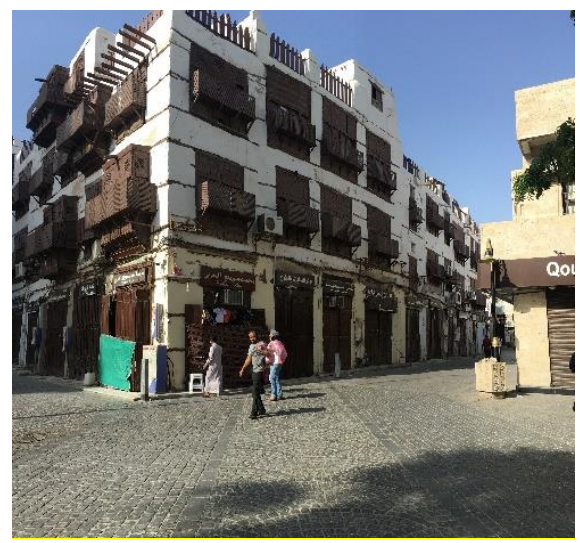


Figure 20: Buildings permit system allows urban buffer area owners to build up to thirteen floors.

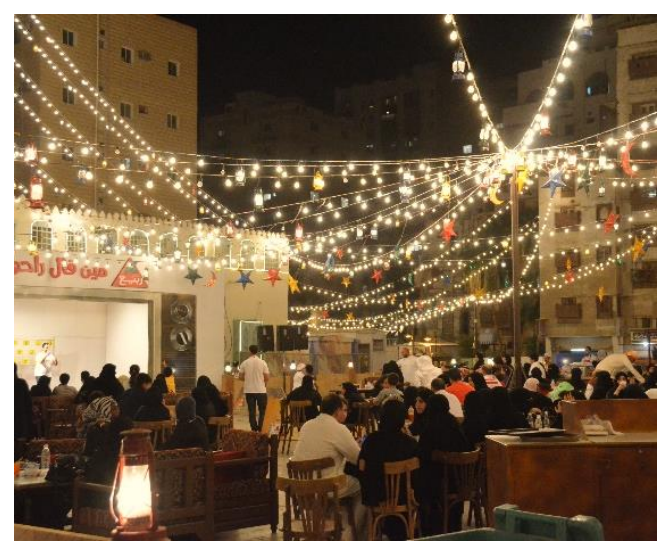

Figure 22: Ramadan nights, unified shop signage, and stylish lighting units enhance the image quality of the maintained spaces.
Figure 21: Tiled flooring, unified shop signage, and stylish lighting units enhance the image quality of the maintained spaces.

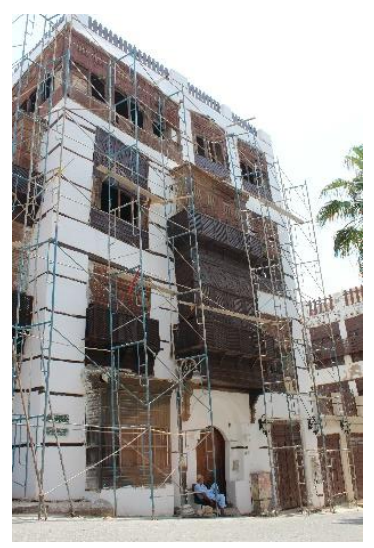

Figure 23: Sample of the continuous efforts of the Conservation Authorities to maintain the listed buildings.

\section{Discussion and Conclusions:}

Literature review and case studies' investigation showed that none of the conservation authorities of the Arab countries had adopted the UNESCO and ICOM definition of heritage in their heritage conservation scope and policies yet [21,62]. Traditional urban fabric, social structure, and intangible urban heritage have been excluded from conservation efforts. Urban heritage areas and their neighboring districts within historic cities in many developing countries suffer from the deteriorated social fabric, low standard services, and utility problems [66]. Meanwhile, In almost all historic cities, planning departments of local municipalities are responsible for historic urban areas. Urban planning authorities are dealing with historic urban centers as part of the deteriorated urban sectors of their cities. Such areas usually require expensive solutions beyond the local governments' financial resources resulting in partial solutions or long-term phased development plans [67]. Although some of these urban revitalization projects were partially successful, they caused the loss of distinctive heritage pieces in other areas across the globe. The Albalad area in Jeddah and Amman presents examples of lost heritage buildings $[62,68]$.

The investigation of Amman city shows that rational urban management policies and suitable adaptive reuse are the keys to prosperous sustainable historic urban heritage. The historic area has been subject to subsequent management plans since 1995. These plans were oriented to improve living conditions, create more job opportunities, ease traffic congestion, and improve environmental quality. Increasing tourism activities were embedded within the current management plan [69]. The development in Amman city in general and the Albalad area, in particular, was based directly on foreign aid, and actions were selected based on the significance of their impacts on residents [39]. Facilities to support cultural and touristic activities were developed, and adaptive reuse for buildings was implemented. The result was a vibrant urban and commercial area. However, Islamic and Roman monuments in the surrounding areas are still undeveloped and require dedicated funds for conservation $[13,70]$.

The case of Jeddah proved that fund availability is not enough. There is a need for a legal and institutional framework to maintain the sustainability of the conserved heritage urban areas [60,62]. Neither the selected adaptive reuse for the listed heritage buildings in Jeddah, as shopping ground floors and offices for typical floors, nor the financial incentives for owners of heritage buildings provide the desired sustainability. On the contrary, 
implemented planning regulations and building codes gave owners of heritage buildings motives to neglect and even demolish their buildings to receive more Floor Area Ratio and different floor usability [4]. These regulations resulted in changing the urban character of the historic area and its urban buffer. As fire accidents hit the historic area several times over the last years resulting in the loss of several historical buildings, the Crown Prince, earlier this year, provided funds to conserve fifty buildings of the listed heritage buildings [62].

Comparing the urban management plans in Amman and Jeddah, it can be concluded that good design and details can produce a positive image, irrespective of the richness of the used materials. The study proved that adaptive reuse should be selected carefully and based on their residents' attractiveness. Successful selection of adaptive reuse for buildings within historic urban areas significantly impacts the urban quality and sustainability. The investigated case studies showed that adopting a legal and financial multi-dimensional framework is essential as the basis for any sustainable urban heritage conservation plans. The study proved its argument that conservation and revitalization activities improve the overall market value of the proprieties within the area and attract a new category of residents [71]. The study also showed that two main factors help create a vital community and sense of belonging; the first one is the economic benefits of locals from the conservation efforts, as the case of refugees in Amman and the replacement population of the Albalad in Jeddah [12,18,39,50]. The second motive for the local community is the sense of belonging that can be achieved through programs of preserving the social structure and conserving intangible heritage. Such programs require smaller budgets than conserving the physical environment and can be sustainable economically $[4,18,57]$.

The study investigation's most important lesson is that sustaining and preserving the intangible heritage does not require capital investment. Unlike conserving the physically built environment, social programs raise the sense of belonging and cultural identity within the local community [15], such as Ramadan nights organized by the Saudi Antiquities Authorities in the Albalad area at Jeddah and the cultural events and activities held in the Albalad area at Amman. These programs proved to be very helpful in raising the local community's awareness of their heritage and gaining their willingness to participate in the conservation process [13,50]. Urban spaces within historic areas are not built to accommodate contemporary traffic means; reducing traffic congestion must be one of the primary targets of any development plans; this will have a direct environmental impact through reducing air pollution [2,21]. Moreover, The investigation proved that improving the quality of the outdoor spaces and enhancing the public space image increase the overall market value of the proprieties within the area and attract a new category of residents and activities [38,39]. Urban buffer areas should be treated to facilitate a smoother transaction between the historic urban and the rest of the city urban areas [25].

"What can be measured can be accomplished": This quote was one of the fundamental outputs of the Millennium Development Goals (MDGs) final report, adopted by the United Nations' Millennium Declaration in 2000 [72]. Therefore, detailed objective and subjective indicators must be defined as soon as the conservation objectives are defined. Data collection of all the existing conditions is required before any efforts of implementation. These data are the base for accurate measuring of the outcome of the actions [38]. The study showed that the best way to perform conservation for historical urban areas is to embed it within the urban planning strategies of the city [68,73]. The case studies' efforts analysis proved that local awareness and public participation contributed positively to improving and revitalizing the place's character. Indeed, urban heritage is an essential part of any local culture.

Residents' sense of belonging and pride can be the driving force for any conservation efforts. Residents' participation is necessary for any urban management plans. Locals should be part of the team to identify the heritage objects, define conservation priorities, management plans, and revitalization activities. Policymakers have to induce regulations 
that ensure effective conservation of cultural values in such historic city centers. Consequently, these cultural values can generate more attractions to those centers and, hence, sustain these places. Some cultural activities, such as social gathering at night, requires special urban qualities to support these social activities. Improving the urban quality of spaces containing social activities is flourishing with improving essential components of the historic city centers. This can inspire practitioners such as architects or urban designers to create spaces that meet the need of the people and enrich their experience in historical and cultural contexts.

Further research is needed in two main areas: the economic bases of urban heritage conservation projects in terms of their validity, alternatives, impacts on the local community prosperity, and the generated wealth distribution. The second area is investigating the development of multi-dimensional performance indicators to assess urban heritage conservation projects. Furthermore, detailed assessment framework for heritage definition, conservation, and preservation of historic city centers to evaluate conservation decisions throughout project phases.

Funding: This research received no funds.

Conflicts of Interest: The author declares no conflicts of interest.

\section{References}

1. Al-Saffar, M. Urban heritage, and conservation in the historic center of Baghdad. International Journal of Heritage Architecture: Studies, Repairs and Maintenance 2017, 2, 23-36, doi:10.2495/ha-v2-n1-23-36.

2. Jasim, S. The Issue of Standardization in Tradition Urban Fabric of Islamic City. In Proceedings of the 13th Internation Conference "Standardization, Prototypes, and Quality: A Means of Balkan Countries' Collaboration, Brasov, Romania, November 3 - 4, 2016.

3. Khalaf, R.W. Traditional vs. modern: Arabian morphologies. Journal of Cultural Heritage Management and Sustainable Development 2012, 2, 27-43, doi:10.1108/20441261211223252.

4. Shehata Ahmed, A.E. Impact of Urban Development Policies on the Produced Urban Characteristics. In Proceedings of the In 3rd International Conference on Conservation of Architectural Heritage (CAH). Aswan, Egypt, 2018.

5. AlSayyad, N. Space in an Islamic City: Some Urban Design. The Journal of Architectural and Planning Research 1987, 4, 11.

6. Mandeli, K. Interpretation of Urban Design Principles in a Traditional Urban Environment: The Role of Social Values in Shaping Cities. University of Southern California, Los Angeles, California, 1993.

7. Nasralden, M.K. The Transformation of Public Spaces in Saudi Cities: A Case Study of Jeddah. In Proceedings of the Saudi International Conference, Coventry, United Kingdome, 2011.

8. Mahmoud, M.L. The Egyptian City Centres in the Islamic Era: Image Analysis, Evaluation and Contemporary Reflection. Journal of Engineering - Sciences Assiut University 2020, 48, 17.

9. UNESCO. Convention Concerning The Protection of the World Cultural and Natural Heritage. 2021, Extended forty-fourth session.

10. Mualam, N.; Barak, N. Evaluating Comparative Research: Mapping and Assessing Current Trends in Built Heritage Studies. Sustainability (Switzerland) 2019, 11, doi:10.3390/su11030677.

11. Correia Jorge, M.T. Traditional Islamic cities unveiled: the quest for urban design regularity. Gremium Magazine 2015, 2.

12. Samargandi, S. Integral Placemaking in Sensitive Heritage Sites for successful cultural tourism. Effat University, Jeddah, 2018.

13. Hannah, D. The Rights to Amman: An exploration of the relationship between a city and its inhabitants. Leiden University, Leiden, Netherlands, 2021.

14. Sylvia, J. Urban Streets: Towards Sustainable Mobility in Arabic Cities. Stuttgart University, Stuttgart 2013. 
15. Yung, E.H.K.; Zhang, Q.; Chan, E.H.W. Underlying social factors for evaluating heritage conservation in urban renewal districts. Habitat International 2017, 66, 135-148, doi:10.1016/j.habitatint.2017.06.004.

16. Ertan, T.; Eğercioğlu, Y. Historic City Center Urban Regeneration: Case of Malaga and Kemeraltı, Izmir. Procedia - Social and Behavioral Sciences 2016, 223, 601-607, doi:10.1016/j.sbspro.2016.05.362.

17. Elseragy Ahmed, E.A., Sabbagh M. Revitalizing Alexandria through its symbolic significance of heritage, urban form, and the distinctive spirit of place. In Proceedings of the International Conference on Changing Cities III: Spatial, Design, Landscape \& Socio-economic Dimensions, Syros, Delos, Mykonos Islands, Greece, June 26-30, 2017; pp. 1819-1834.

18. Janset, S. Al-Balad as a place of heritage: problematizing the conceptualization of heritage in the context of Arab Muslim Middle East. University College London, London, 2011.

19. Koorosh, S.S.; Sza, I.; Ahad, F. Evaluating Citizens' Participation in the Urban Heritage Conservation of Historic Area of Shiraz. Procedia - Social and Behavioral Sciences 2015, 170, 390-400, doi:10.1016/j.sbspro.2015.01.049.

20. Pilder, A.D. Urbanization and Identity: The Building of Amman in the Twentieth Century. Miami University, Oxford, Ohio, 2011.

21. Abdeljawad, N.; Nagy, I. Urban Environmental Challenges and Management Facing Amman Growing City. Review of International Geographical Education (RIGEO) 2021, 11, 2021-2021, doi:10.48047/rigeo.11.05.192.

22. Katapidi, I. Heritage policy meets community praxis: Widening conservation approaches in the traditional villages of central Greece. Journal of Rural Studies 2021, 81, 47-58, doi:10.1016/j.jrurstud.2020.09.012.

23. LUCK, EC Cultural Genocide and the Protection of Cultural Heritage; The J. Paul Getty Trust: Los Angeles, 2018.

24. Mady Mohamed, E.M. Investigating the Environmental Performance of the Wind Catchers in Jeddah. WIT Transactions on The Built Environment 2018, 177, 11.

25. UNESCO, I., City of Lyon, WHC. Developing Historic Cities Key Understanding and Taking Actions; 2014.

26. Zancheti Silvio Mendes, K.S. Measuring Heritage Performance. In Proceedings of the In 6th International Seminar on Urban Conservation Pernambuco, Brazil, 2012.

27. Convention, U.a.W.H. Operational Guidelines for the Implementation of the WORLD HERITAGE CENTRE: Paris, France, 2019; pp. 1-177.

28. UNESCO. Convention Concerning The Protection of the World Cultural and Natural Heritage. July 2018, 42nd session.

29. UNESCO. Convention For the Safeguarding of the Intangible Cultural Heritage. 2003.

30. Hoff, A.G. Sacred Placemaking and Urban Policy The Case of Tepoztlán, Mexico. The University of California, IRVINE, 2020.

31. Fadli, F.; Alsaeed, M. A holistic overview of Qatar's (Built) cultural heritage; Towards an integrated sustainable conservation strategy. Sustainability (Switzerland) 2019, 11, doi:10.3390/su11082277.

Richards, G.; King, B.; Yeung, E. Experiencing culture in attractions, events and tour settings. Tourism Management 2020, 79, doi:10.1016/j.tourman.2020.104104.

33. Edwards, B.; Frasch, T.; Jeyacheya, J. Evaluating the effectiveness of land-use zoning for the protection of built heritage in the Bagan Archaeological Zone, Myanmar-A satellite remote-sensing approach. Land Use Policy 2019, 88, doi:10.1016/j.landusepol.2019.104174.

34. ICOMOS. Heritage supports the \#GlobalGoals Join the Movement! 2018.

35. Smith, L. Uses of Heritage; Routledge: New York, 2006.

36. ICOMOS, A. Burra Charter. 2013.

37. Charter, A.I.B. The Burra Charter Process. 2013.

38. Francesca, N. The Role of Cultural Heritage in Sustainable Development Multidimensional Indicators as Decision Making Tool Enhanced Reader. Sustainability 2017, 9, 28. 
39. Ashour, KN Urban Regeneration Strategies in Amman's Core: Urban Development and Real Estate Market. Dortmund Technical University, Dortmund, 2016.

40. Andrew, T. Urban Regeneration in the UK; Routledge: London and New York, 2021.

41. Alnsour, J.A. Managing urban growth in the city of Amman, Jordan. Cities 2016, 50, 93-99, doi:10.1016/j.cities.2015.08.011.

42. Abu-Dayyeh, N.I. Persisting vision: Plans for a modern Arab capital, Amman, 1955-2002. Planning Perspectives 2004, 19, 79110, doi:10.1080/0266543042000177922.

43. ICOMOS. International Charter For the Conservation and Restoration of Monuments and Sites (The Venice Charter). 1964.

44. ICOMOS. Charter for the Protection and Management of the Archaeological Heritage. 1990.

45. ROBERTS PETER, SH Urban Regeneration; SAGE: London and California, 2017.

46. Montgomery, J. Cultural Quarters as Mechanisms for Urban Regeneration. Part 1: Conceptualising Cultural Quarters; 2003; Volume 18, pp. 293-306.

47. Pietrostefani, E.; Holman, N. The politics of conservation planning: A comparative study of urban heritage making in the Global North and the Global South. Progress in Planning 2021, 152, doi:10.1016/j.progress.2020.100505.

48. Ji, X.; Shao, L.; Du, Y. Collaborating with local communities to identify improvement priorities for historic urban landscape based on residents' satisfaction: An application of asymmetric impact-performance analysis in dandong, China. Sustainability (Switzerland) 2020, 12, 1-16, doi:10.3390/su12041463.

49. Yousof, A.S. Plaza Design Criteria- Applied Study of South East Plaza of the Grand Mosque at Makkah. Umm Al-Qura university, Makkah, 2018.

50. Badawy Samaa, SA Sustainable Urban Heritage Conservation Strategies - Case Study of Historic Jeddah Districts. In CITIES' IDENTITY THROUGH ARCHITECTURE AND ARTS, Anna Catalani, Z.N., Antonella Versaci, Dean Hawkes, Hocine Bougdah, Adolf Sotoca, Mahmoud Ghoneem, Ferdinando Trapani, Ed.; Routledge: Cairo, Egypt., 2020; Volume 1, p. 17.

51. Kong, P. Social Quality in the Conservation Process of Living Heritage Sites. Delft University of Technology, Delft, Netherlands, 2008.

52. Abdulaal, W.A. Large urban developments as the new driver for land development in Jeddah. Habitat International 2012, 36, 36-46, doi:10.1016/j.habitatint.2011.05.004.

53. Statistics, D.o. Tourism Statistics: Statistical Yearbook of Jordan 2020; 2020.

54. Statistics, D.o. Population Jordan Statistics. 2018.

55. Statistics, D.o. Amman Vital Statistics. 2020.

56. Affairs, M.o.M. Future Saudi Cities Programme City Profiles Series: - jeddah City Profile; Ministry of Municipal Affairs: Jeddah, 2019.

57. Saad, R.T. Investigating the Cultural Landscape Identity of Jeddah, KSA WIT Transactions on The Built Environment 2018, $177,11$.

58. BEEAH, P., Architects and Engineers. Jeddah Urban Strategic Plan; Jeddah Municipality: Jeddah, Sadi Arabia, 2004.

59. Bokhari, AY Conservation in the Historic District of Jeddah. In Proceedings of the Redeveloping and Rebuilding Traditional Areas, Jeddah, 2011.

60. Commission, SH State of Conservation Report - KINGDOM OF SAUDI ARABIA WORLD HERITAGE SITES; Jeddah, 2020.

61. Heritage/SCTA, R. Historic Jeddah the Gate to Makkah. 2012.

62. UNESCO. State of Conservation: Historic Jeddah, the Gate to Makkah (Saudi Arabia); UNESCO World Heritage Centre: 2021.

63. Ahmed, M.K.N. Public Spaces in a Contemporary Urban Environment: Multi-dimensional Urban Design Approach for Saudi Cities. University of Newcastle, Newcastle, 2011.

64. The Supreme Commission for Tourism, KSA. National Tourism: Development Project Phase 1: GENERAL STRATEGY; July, 2002.

65. Ismail, D.A.-M. A Case Study in Planning Implementation. Dept. of Town and Country Planning 1993, Ph.D, 28. 
66. Lai, L.W.C.; Lorne, F.T. Sustainable urban renewal and built heritage conservation in a global real estate revolution. Sustainability (Switzerland) 2019, 11, doi:10.3390/su11030850.

67. Udeaja, C.; Trillo, C.; Awuah, K.G.B.; Makore, B.C.N.; Patel, D.A.; Mansuri, L.E.; Jha, K.N. Urban heritage conservation and rapid urbanization: Insights from Surat, India. Sustainability (Switzerland) 2020, 12, doi:10.3390/su12062172.

68. De Medici, S.; De Toro, P.; Nocca, F. Cultural heritage, and sustainable development: Impact assessment of two adaptive reuse projects in Siracusa, Sicily. Sustainability (Switzerland) 2020, 12, doi:10.3390/su12010311.

69. Ali Al-Shomali, M. Establishing evaluation criteria of modern heritage conservation in historic city centers in Jordan. International Journal of Environmental Science and Development 2020, 11, 561-571, doi:10.18178/ijesd.2020.11.12.1308.

70. Mais, A. Emerging Public Spaces in the City of Amman. Dortmund University, Dortmund, 2014.

71. Jayantha, W.M.; Yung, E.H.K. Effect of Revitalization of Historic Buildings on Retail Shop Values in Urban Renewal: An Empirical Analysis. Sustainability (Switzerland) 2018, 10, doi:10.3390/su10051418.

72. Nations, U. The Millennium Development Goals Report; United Nations: New York, 2015.

73. García-Hernández, M.; Manuel de la, C.-V.; Claudia, Y. Cultural heritage and urban tourism: Historic city centres under pressure. Sustainability (Switzerland) 2017, 9, doi:10.3390/su9081346. 